\title{
THE MINERAL COMPOSITION OF HERBAL DRUG OF SAFFLOWER (CARTHAMUS TINCTORIUS. L.)
}

Study of the mineral composition of plant material of safflower, flowers, seeds and herb was carried out. Atomic emission spectrographic method was used and contents of 15 elements were determined. The experimental data indicate quite diverse and abundant element content in safflower material that determines its therapeutic effect. The results of analysis show elements of content that safflower herb contains the largest amount, and the seeds lowest. The total amount of all elements of the studied material of safflower $(\mathrm{mg} / 100 \mathrm{~g})$ as follow herbs: 6827.08; flowers: 3507.01; seeds: 1160.56.

Key words: safflower; mineral composition; atomic emission spectrophotometry; ash; macro- and microelements

\section{INTRODUCTION}

Pharmacological effects of plants are the result of systemic effects on the body of separate biologically active substances (BAS) and it is combination. Besides herbs have very diverse chemical composition, it is a natural source of mineral compounds in which mineral are most available shape for absorption for the body and biologically available concentrations, and therefore have a higher physiological activity compared with synthetic analogs [7].

This responsible role of chemical elements are explained because they are part of the respiratory pigments, vitamins, hormones, enzymes and coenzymes, secondary substances involved in the regulation of life processes [12,15].

In practical point of view information about the chemical composition of food and medicinal plants are very important for balanced nutrition, prevention and treatment of diseases $[9,11,13,14]$.

Natural herbal compounds and drugs based on occupation of a significant place in modern medicine. To date, for the treatment of diseases are used about 600 types of herbal drugs. One of these plants is safflower (lat. Carthamus tinctorius. L.) - annual plant of the family Asteraceae or Compositae [8, 9, 12].

Safflower is widely used in many industries, different countries have it's own traditions and culture use - food, pharmaceutical, cosmetic, feed. But mainly it is known as oilseeds, because seeds contain 32 to $39 \%$ semi-drying oil (in the nucleus 50-56\%). The product contains polyunsaturated fatty acids (linoleic, linolenic and other omega acids), which protect the body from atherosclerotic plaques, fat-soluble vitamins $\mathrm{E}$ and $\mathrm{C}$, derivatives of serotonin (a substance sometimes called "hormone of joy or satisfaction"), and some glycosides [10].

(c) Barashovets O. V., Popova N. V., 2016
Safflower contains in its composition inulin which helps to normalize blood glucose levels, showing choleretic, diuretic, regulates thyroid function $[6,7,9,12]$.

The flowers, in addition, contain a red pigment carthamin (or carthamus red) and yellow carthamus A and B (saflomin A and B), carthamidin, iso-carthamin, polysaccharides, essential oil, lignans.

Safflower flowers are used for coloring all shades of yellow and orange colors, including food.

Safflower is used to treat wounds and burns, pyoderma and pemphigus of different forms. In Chinese medicine, safflower flowers are widely prescribed in gynecological diseases. Infusion of flowers has choleretic and laxative effect.

The aim is to study the mineral composition of safflower materials, which take into account when developing indexes for the draft of pharmacopoeia monograph of plant material $[2,3,5,9]$.

\section{MATERIALS AND METHODS}

Seeds were harvested in the period of full maturity in 2014 at the experimental area of the botanical garden of NPhU, flowers and herb - during flowering time.

Study of the mineral composition of different plant materials: flowers, seeds and herb was carried out. For this it has been used sophisticated methods of analysis atomic emission spectrographic method based on evaporation plant's ash in the arc discharge, photographic registration decomposed into a spectrum of radiation and measuring the intensity of the spectral lines of certain elements [11].

Preparing samples for analysis consisted of careful carbonization plant material when heated in a muffle furnace $\left(\mathrm{t}^{\circ}\right.$ up to $\left.500^{\circ} \mathrm{C}\right)$ with pre-treatment samples by diluted sulfuric acid. Evaporation of tests conducted with 
craters graphite electrodes in arc discharge of alternating current (source excitation spectra of type IVS-28) at a current $16 \mathrm{~A}$ and 60 seconds exposure. To obtain spectra and their registration plate used in spectrograph DFS-8 with a diffraction grating $600 \mathrm{shtr} / \mathrm{mm}$ and trilenz system coverage gap. Determination of intensity of the lines in the spectra of analyzed samples and calibration samples (GF) was performed using microphotometer MF-1.

Photographing the spectra were carried out in the following conditions: amperage stream arc AC - 16A, the ignition phase $-60^{\circ} \mathrm{C}$, frequency pulse ignited -100 bits per second; analytical gap - $2 \mathrm{~mm}$, width of the slit of the spectrograph $-0.015 \mathrm{~mm}$; exposure -60 seconds. Photographed spectra in the wavelength range $230-330 \mathrm{~nm}$. Using standard samples metal salt solutions (ISORM-23-27) in the range of measurable concentrations built calibration curve, which determined regarding each element of its ash contents. The contents of minerals was calculated using the following expression, (\%):

$$
X=\frac{a \cdot m}{M},
$$

where: $\mathrm{m}$ - mass of ash, g; M - mass of safflower material / extract, g; a - the contents of the element in the ash, \%.

\section{RESULTS AND DISCUSSION}

Ash is residue of inorganic substances obtained after burning and calcining materials. There are a total ash and ash insoluble in hydrochloric acid solution. The study was carried out in accordance with requirement of Ukrainian State Pharmacopoeia [2, 3].

Total ash is composed of minerals safflower material and foreign mineral impurities (earth, sand, stones) caught in raw materials when cleaning and drying.

Determination of total ash was carried out in the scientific and technological complex "Institute of Monocrystals" NAS of Ukraine (Kharkov). The results are shown in Tab. 1.

Results of the analysis of the elemental composition of flowers, herb and safflower seeds are represented in Tab. 2. In the studied material, 15 minerals were found, among which 5 belong to macroelements and 10 to microelements (Tab. 2).

The results show that safflower herb contains the largest amount of elements, seeds - smallest. According to the result it can be establish a pattern for the content of elements in the herb safflower: $\mathrm{K}>\mathrm{Ca}>\mathrm{Si}>\mathrm{Mg}>\mathrm{P}>$ $\mathrm{Na}>\mathrm{Fe}>\mathrm{Al}>\mathrm{Sr}>\mathrm{Mn}>\mathrm{Zn}$. For flowers, it has the following view: $\mathrm{K}>\mathrm{Ca}>\mathrm{Si}>\mathrm{Mg}>\mathrm{P}>\mathrm{Na}>\mathrm{Fe}>\mathrm{Al}>\mathrm{Zn}>\mathrm{Sr}>$ $\mathrm{Mn}$, and for seed as follow: $\mathrm{K}>\mathrm{Ca}>\mathrm{Si}>\mathrm{Mg}>\mathrm{P}>\mathrm{Na}>$ $\mathrm{Al}>\mathrm{Zn}>\mathrm{Mn}>\mathrm{Fe}>\mathrm{Cu}$. Total sum of all elements of the studied material (mg/100 g) are herb: 6827.08; flower: 3507.01; seeds: 1160.56 .

It should be noted that safflower material contains a number of important elements (mg/100 g), potassium herb-4110, 2040-flower seeds, 630; calcium - herb-1090 flowers-680 seeds, 170; magnesium - herb-410, flowers-205
Table 1

ASH CONTENT OF SAFFLOWER PLANT MATERIAL

\begin{tabular}{|l|c|}
\hline \multicolumn{1}{|c|}{ Plant material } & Ash, \% \\
\hline Safflower herb & 13.74 \\
\hline Safflower, flowers & 6.84 \\
\hline Safflower seeds & 2.11 \\
\hline
\end{tabular}

Table 2

THE MINERAL COMPOSITION OF SAFFLOWER'S HERB, FLOWERS AND SEEDS

\begin{tabular}{|l|c|c|c|}
\hline \multirow{2}{*}{\multicolumn{1}{|c|}{ Element }} & \multicolumn{3}{|c|}{ Element contents, mg/100 g } \\
\cline { 2 - 4 } & $\begin{array}{c}\text { Safflower } \\
\text { herb }\end{array}$ & $\begin{array}{c}\text { Safflower } \\
\text { flowers }\end{array}$ & $\begin{array}{c}\text { Safflower } \\
\text { seeds }\end{array}$ \\
\hline Sodium (Na) & 140 & 54 & 31 \\
\hline Potassium (K) & 4110 & 2040 & 630 \\
\hline Calcium (Ca) & 1090 & 680 & 170 \\
\hline Magnesium (Mg) & 410 & 205 & 85 \\
\hline Phosphorus (P) & 275 & 135 & 52 \\
\hline Silicon (Si) & 685 & 410 & 150 \\
\hline Iron (Fe) & 48 & 24 & 6.3 \\
\hline Aluminum (Al) & 34 & 17 & 21 \\
\hline Zinc (Zn) & 2.1 & 6.8 & 13.7 \\
\hline Copper (Cu) & 0.68 & 0.68 & 1.0 \\
\hline Manganese (Mn) & 6.8 & 3 & 11 \\
\hline Molybdenum (Mo) & $<0.03$ & $<0.03$ & $<0.03$ \\
\hline Lead (Pb) & $<0.03$ & $<0.03$ & $<0.03$ \\
\hline Nickel (Ni) & 0.10 & 0.07 & 0.14 \\
\hline Strontium (Sr) & 13.7 & 3.4 & 1.0 \\
\hline
\end{tabular}

seeds, 84; iron - herb-48, 24-flower seeds-63, sodium herb-140, 54-flower seeds-31.

Safflower material has a great interest as a source of important elements - potassium and calcium.

The contents of harmful elements ( $\mathrm{Co}, \mathrm{Cd}, \mathrm{As}, \mathrm{Hg}$ ) in safflower material meets the requirement of Ukrainian State Pharmacopoeia [2, 3].

\section{CONCLUSIONS}

1. By the method of atomic emission spectrophotometry, the elemental composition of safflower material was determined. 15 macro- and microelements were identified in objects that were investigated.

2. The experimental data indicate quite diverse and abundant element contents in safflower material that determines its therapeutic effect. Five macroelements (Na, K, Ca, Mg, P) and 10 micro-elements (Fe, Si, Al, Mn, Pb, Ni, Mo, Cu, Zn, Sr) were identified.

3. The contents of micro- and macro mineral of safflower material situated in sequence and with different amount of elements: herb - 6827.08; flower 3507.01; seeds - 1160.56 .

\section{REFERENCES}

1. Горницкий К. С. Заметки об употреблении в народном быту некоторых дикорастущих и разво- 
димых растений украинской флоры. - Х., 1987. 220 c.

2. Державна фармакопея України / Державне підприємство «Науково-експертний фармакопейний центр». - 1-е вид. - Х.: РІРЕГ, 2001. - Доп. 1. 2004. - 520 c.

3. Державна фармакопея України / Державне підприємство «Український науковий фармакопейний центр якості лікарських засобів». - 1-е вид. Доп. 3. - Х.: Державне підприємство «Український науковий фармакопейний центр якості лікарських засобів», 2009. - 280 с.

4. Драгомирецкий Ю. Целебные свойства жиров и масел: [учеб.]. - Донецк: Сталкер, 1997. - 347 с.

5. Котов А. Г. Дослідження з розробки та введення монографій на лікарську рослинну сировину до Державної фармакопеї України // Фармаком. 2009. - № 1. - С. 5-19.

6. Куркин А. В. Флавоноиды фармакопейных растений. - Самара: 000 «Офорт», ГБОУ ВПО СамГМУ Минздравсоцразвития России, 2012. - 290 с.
7. Полежаева И. В. Аминокислотный и минеральный состав вегетативной части Chamerionangustifolium (L.) Holub / И. В. Полежаева, Н. И. Полежаева, Л. Н. Меняйло // Хим.-фарм. журн. - 2007. - № 3. C. 27-29.

8. Попова Н. В. Лекарственные растения мировой флоры / Н. В.Попова, В. И. Литвиненко. - Х.: СПДФО Мосякин В. Н., 2008. - 510 с.

9. Практикум з ідентифікації лікарської рослинної сировини: [навч. посіб.] / [В. М. Ковальов, С. М. Марчишина, О. П. Хворост та ін.]; за ред. В. М. Ковальова, С. М. Марчишин. - Тернопіль: ТДМУ, 2014. $264 \mathrm{c}$.

10. Сельскохозяйственная энциклопедия. - М.: Советская энциклопедия, 1974. - С. 483.

11. Фурса Н. С. Изучение элементного состава валерианы лекарственной / Н. С. Фурса, Д. С. Круглов // Фармация. - 2012. - № 5. - С. 18-21.

12. Шотт П. Р. Сафлор красильный - ценная масличная и лекарственная культура / Пища. Экология. Качество. - Новосибирск, 2002. - 301 с. 


\section{УДК 615.322:582.998.16:633.85:54.061/.062}

\section{0. В. Барашовець, Н. В. Попова}

\section{ЕЛЕМЕНТНИЙ СКЛАД СИРОВИНИ САФЛОРУ КРАСИЛЬНОГО (CARTHAMUS TINCTORIUS. L.)}

Було проведено дослідження елементного складу рослинної сировини сафлору красильного: квіток, насіння, трави. Для цього був використаний атомно-емісійний спектрографічний метод, визначено вміст 15 елементів. Отримані експериментальні дані свідчать про достатньо різноманітний та багатий елементний склад та вміст у досліджуваній сировині, що й обумовлює ï терапевтичну дію. Результати дослідження вмісту мікроелементів свідчать про те, що трава сафлору містить їх найбільшу кількість, а насіння - найменшу. Вміст загальної суми всіх елементів досліджуваної сировини сафлору красильного (мг/100 г): трава - 6827,08; квітки 3507,01 ; насіння - 1160,56.

Ключові слова: сафлор красильний; елементний склад; зола; атомно-емісійна спектрофотометрія

\section{УДК 615.322:582.998.16:633.85:54.061/.062}

0. В. Барашовец, Н. В. Попова

\section{ЭЛЕМЕНТНЫЙ СОСТАВ СЫРЬЯ САФЛОРА КРАСИЛЬНОГО (CARTHAMUS TINCTORIUS. L.)}

Было проведено исследование элементного состава различного растительного сырья сафлора красильного: цветков, семян, травы. Для этого был использован один из сложных методов анализа - атомно-эмиссионный спектрографический метод. Определено содержание 15 элементов. Полученные экспериментальные данные свидетельствуют о достаточно разнообразном и богатом элементном содержании в исследуемом сырье, что и обусловливает его терапевтическое действие. Результаты исследования содержания микроэлементов свидетельствуют о том, что трава сафлора содержит их наибольшее количество, а семян - наименьшее. Общая сумма всех элементов исследуемого сырья (мг/100 г): трава - 6827,08; цветки - 3507,01; семена $-1160,56$.

Ключевые слова: сафлор красильний; элементный состав; зола; атомно-эмиссионная спектрофотометрия

Адреса для листування:

61118, м. Харків, вул. Валентинівська, 4.

Національний фармацевтичний університет
Надійшла до редакції 25.05.2016 р. 